\title{
A STUDY OF HAEMATOLOGICAL MANIFESTATIONS IN HIV POSITIVE PATIENTS- CORRELATION WITH CD4 COUNT
}

\author{
Madhu Balla1, Vijay Kumar², K. K. Koul ${ }^{3}$ \\ 1Postgraduate, Department of Pathology, Government Medical College, Jammu, Jammu and Kashmir, India. \\ ${ }^{2}$ Registrar, Department of Medicine, Government Medical College, Jammu, Jammu and Kashmir, India. \\ 3Professor, Department of Pathology, Government Medical College, Jammu, Jammu and Kashmir, India.
}

\section{BACKGROUND}

ABSTRACT

HIV infection is a multisystem disease and haematological abnormalities are among the most common complications of HIV. HIV associated haematological abnormalities seem to be dependent on the level of virus replication, as these abnormalities are severe in late stage AIDS patients with high viremia. ${ }^{1,2}$ These abnormalities reflect the underlying immune status and may be prevented or corrected by use of highly active antiretroviral therapy (HAART). Haematological abnormalities such as impaired haematopoiesis, immune and non-immune mediated cytopenias, and altered coagulation have been described in patients with HIV infection/AIDS. We wanted to evaluate the various haematological parameters in HIV patients and their association with CD4 counts.

\section{METHODS}

One hundred HIV positive patients, symptomatic as well as asymptomatic, diagnosed by enzyme-linked immunosorbent assay (ELISA) method according to the National AIDS Control Organization (NACO) guidelines were included. Complete haematological profile was recorded. Relationship between CD4 counts and various haematological parameters were analysed. Association between two attributes was calculated and $p$ value of less than 0.05 was considered statistically significant.

\section{RESULTS}

The most common haematological abnormality was anaemia, seen in $93 \%(n=93)$ of patients. Normocytic normochromic anaemia was seen in $42 \%$ of patients, which was the most common type followed by normocytic hypochromic in 25 (25\%) cases. A strong association between anaemia and CD4 counts was observed. Other haematological parameters also showed corresponding low values with decreasing CD4 counts.

\section{CONCLUSIONS}

HIV affects virtually all organ systems, with well-known abnormalities related to hematopoietic system. Anaemia being the most common abnormality has strong correlation with CD4 counts and therefore could be used to predict the development of a more advanced disease.

HOW TO CITE THIS ARTICLE: Balla M, Kumar V, Koul KK. A study of haematological manifestations in HIV positive patientscorrelation with CD4 count. J. Evolution Med. Dent. Sci. 2019;8(19):1545-1549, DOI: 10.14260/jemds/2019/343

\section{BACKGROUND}

Human Immunodeficiency virus belongs to family of human retroviruses. HIV infection is marked by progressive decrease in the number of circulating $\mathrm{CD}_{4}+\mathrm{T}$ helper cells, which over a period of years leads to immunological decline and death due to opportunistic infections and neoplasms. HIV causes the Acquired Immunodeficiency syndrome (AIDS). ${ }^{3}$ AIDS is either characterized by the presence of a particular opportunistic infection or the $\mathrm{CD}_{4}+\mathrm{T}$ lymphocyte count being $<200 / \mathrm{mm}^{3}$ or a combination of both. 4

In India the first AIDS case was detected in 1986 among female sex workers in Chennai and since then HIV infection has been reported in all states and union territories. ${ }^{5}$ India is home to second largest population of people living with HIV and AIDS.

'Financial or Other Competing Interest': None.

Submission 27-03-2019, Peer Review 30-04-2019,

Acceptance 06-05-2019, Published 13-05-2019.

Corresponding Author:

Vijay Kumar,

R/O Doulah, P/O Dullangal,

Tehsil Bani Kathua,

Jammu and Kashmir,

India.

E-mail: drvijaygmc97@gmail.com

DOI: $10.14260 /$ jemds $/ 2019 / 343$
HIV infection is a multisystem disease and haematological abnormalities are among the most common complications of HIV. ${ }^{2}$ Haematological abnormalities such as impaired haematopoiesis, immune and non-immune mediated cytopenias and altered coagulation have been described in patients with HIV infection/AIDS. ${ }^{4}$

\section{Aims and Objectives}

The aim of the study was to evaluate the various haematological parameters in HIV patients and their association with CD4 counts.

\section{METHODS}

The present study was a one-year observational study conducted from 1st October 2016 to 31st September 2017 in Haematology wing of Postgraduate Department of Pathology Government Medical College, Jammu. One hundred patients, seropositive for HIV by ELISA were included in the study. Ethical clearance from the institutional ethical committee was obtained. These patients were observed in detail and complete data of each patient was prepared. Complete haematological evaluation including $\mathrm{CD}_{4}$ count was done. Blood collected in a sterile EDTA containing tube and processed following our established laboratory protocol and universal precautions as per guideline of National AIDS Control Organisation (NACO, India).Written informed consent was taken from all. 


\begin{tabular}{|c|c|c|}
\hline \multirow{2}{*}{$\begin{array}{c}\text { Age Distribution } \\
\text { (Years) }\end{array}$} & Male (n=58) & Female (n=42) \\
\cline { 2 - 3 }$\leq 20$ & $1(1.72)$ & $3(7.14)$ \\
\hline $21-30$ & $8(13.79)$ & $15(35.71)$ \\
\hline $31-40$ & $29(50.00)$ & $19(45.24)$ \\
\hline $41-50$ & $11(18.97)$ & $2(4.76)$ \\
\hline $51-60$ & $8(13.79)$ & $3(7.14)$ \\
\hline$>60$ & $1(1.72)$ & $0(0.00)$ \\
\hline Mean Age \pm SD & \multicolumn{2}{|c|}{$36.59 \pm 9.12$} \\
\hline \multicolumn{2}{|c|}{$<0.0001$} \\
\hline p-value & \multicolumn{2}{|c|}{ Table 1. Distribution of Patients According to Age and Sex } \\
\hline
\end{tabular}

\begin{tabular}{|c|c|c|}
\hline History & Number of Patients & Percentage \\
\hline Arthralgia & 1 & 1.0 \\
\hline Asymptomatic & 40 & 40.0 \\
\hline Chronic back ache & 1 & 1.0 \\
\hline Decreased appetite & 1 & 1.0 \\
\hline Diarrhoea & 10 & 10.0 \\
\hline Disseminated TB & 1 & 1.0 \\
\hline Extrapulmonary TB & 7 & 7.0 \\
\hline Left hemiparesis, Brain & 1 & 1.0 \\
\hline TB & 2 & 2.0 \\
\hline Miliary TB & 2 & 2.0 \\
\hline Pulmonary TB & 1 & 1.0 \\
\hline Right axillary LAP/TB & 14 & 3.0 \\
\hline Easy fatiguability & 2 & 14.0 \\
\hline Fever & 3 & 2.0 \\
\hline Fungal infection & 1 & 3.0 \\
\hline Loss of weight & 1 & 1.0 \\
\hline Lymphadenopathy & 2 & 2.0 \\
\hline Oral ulcers & 2 & 2.0 \\
\hline Seizures & 4 & 4.0 \\
\hline Severe anaemia, chronic \\
diarrhoea
\end{tabular}

\begin{tabular}{|c|c|c|}
\hline Anaemia & $\begin{array}{c}\text { Number of } \\
\text { Patients }\end{array}$ & Percentage \\
\hline Non anaemia & & \\
\hline Males (Hb>13 gm \%) & 4 & 4.0 \\
\hline Females (Hb>12 gm \%) & 3 & 3.0 \\
\hline Mild & & \\
\hline Males (Hb 10-13 gm \%) & 26 & 26.0 \\
\hline Females (Hb 10-12 gm \%) & 15 & 15.0 \\
\hline Moderate & & 23.0 \\
\hline Males (Hb 7.0-9.9 gm \%) & 23 & 23.0 \\
\hline Females (Hb 7.0-9.9 gm \%) & 23 & 6.0 \\
\hline Severe (Hb<7.0 gm \%) & 6 & 5.0 \\
\hline Males (Hb<7.0 gm \%) & 5 & 1.0 \\
\hline Females (Hb<7.0 gm \%) & 1 & $<0.0001$ \\
\hline p-value & \multicolumn{2}{|c|}{} \\
\hline Table 3. Haematological Abnormalities
\end{tabular}

\begin{tabular}{|c|c|}
\hline Patterns of Blood Picture & $\begin{array}{c}\text { Number of Patients (\%) } \\
\text { Baseline (n=100) }\end{array}$ \\
\hline Macrocytic & $10(10.0)$ \\
\hline Microcytic hypochromic & $23(23.0)$ \\
\hline Normocytic hypochromic & $25(25.0)$ \\
\hline Normocytic normochromic & $42(42.0)$ \\
\hline \multicolumn{2}{|c|}{ Table 4. Morphological Patterns of Anaemia } \\
\hline
\end{tabular}

\begin{tabular}{|c|c|}
\hline $\begin{array}{c}\text { Haematological } \\
\text { Abnormalities }\end{array}$ & $\begin{array}{c}\text { Number of Patients (\%) } \\
\text { Baseline (n=100) }\end{array}$ \\
\hline Neutropenia & $3(3.0)$ \\
\hline Leucopenia & $2(2.0)$ \\
\hline Lymphocytopenia & $18(18.0)$ \\
\hline $\begin{array}{c}\text { RBC Count }\left(\mathrm{m} / \mathrm{mm}^{3}\right) \\
(<3.8-F e m a l e s)\end{array}$ & $28(28.0)$ \\
\hline $\begin{array}{c}\text { RBC Count }\left(\mathrm{m} / \mathrm{mm}^{3}\right) \\
(<4.5-M a l e s)\end{array}$ & $49(49.0)$ \\
\hline \multicolumn{2}{|c|}{ Phrombocytopenia } \\
\hline Table 5. Haematological Abnormalities in HIV Infected \\
\hline
\end{tabular}

\begin{tabular}{|c|c|c|c|c|c|c|c|}
\hline \multirow{3}{*}{\begin{tabular}{|c|}
$\begin{array}{c}\text { CD4 Count } \\
\text { (cells/ } / \boldsymbol{\mu l} \text { ) }\end{array}$ \\
$\begin{array}{c}\mathrm{Hb} \\
(\mathrm{gm} / \mathrm{dl})\end{array}$ \\
\end{tabular}} & \multicolumn{6}{|c|}{ Mean \pm Standard Deviation } & \multirow{3}{*}{\begin{tabular}{|c|}
$\begin{array}{c}\text { p- } \\
\text { Value }\end{array}$ \\
$<0.0001$ \\
\end{tabular}} \\
\hline & \multicolumn{2}{|c|}{$<200$} & \multicolumn{2}{|c|}{$200-400$} & \multicolumn{2}{|c|}{$\geq 500$} & \\
\hline & 9.02 & 1.33 & 10.48 & 1.73 & 45 & \pm 2.26 & \\
\hline & 3.30 & \pm 0.38 & 76 & 055 & 3.75 & 99 & $<0.000$ \\
\hline & 99 & $\begin{array}{c} \pm \\
1943.07\end{array}$ & 717 & $\begin{array}{c} \pm \\
2355.67\end{array}$ & 7250 & 0 & .215 \\
\hline & & & & & & & \\
\hline & & & & & & & \\
\hline & & & & & & & \\
\hline & & 2 & & 1.03 & & 1.26 & 95 \\
\hline & 3 & $\begin{array}{c} \pm \\
1485.79\end{array}$ & 4 & $\begin{array}{c} \pm \\
1990.71\end{array}$ & 4 & $\begin{array}{c} \pm \\
939.97\end{array}$ & 0.220 \\
\hline & 9 & $\begin{array}{c} \pm \\
680.95\end{array}$ & 2 & $\begin{array}{c} \pm \\
602.88\end{array}$ & 2 & $\begin{array}{c} \pm \\
888.45\end{array}$ & 0.056 \\
\hline & 1.81 & \pm 0.35 & 1.86 & \pm 0.47 & 2.07 & \pm 0.38 & 0.37 \\
\hline \multicolumn{8}{|c|}{$\begin{array}{c}\text { arison of Haematological } \\
\text { CD4 Counts }\end{array}$} \\
\hline
\end{tabular}

\begin{tabular}{|c|c|c|c|}
\hline Authors & $\begin{array}{c}\text { No. of } \\
\text { Anaemia } \\
\text { Cases }\end{array}$ & Total Cases & Percentage \\
\hline Karcher et al & 175 & 197 & $89 \%$ \\
\hline Tripathi et al & 61 & 74 & $82.4 \%$ \\
\hline Sitalakshmi et al & 27 & 42 & $64.2 \%$ \\
\hline Kaloutsi et al & 34 & 40 & $85 \%$ \\
\hline Parinitha et al & 210 & 250 & $84 \%$ \\
\hline Rahman et al & 103 & 204 & $50.5 \%$ \\
\hline Present study & 93 & 100 & $93 \%$ \\
\hline
\end{tabular}

Table 7. Comparison Number of Anaemia Cases in Present Study with Other Studies 


\section{Inclusion Criteria}

This was an observational study and was conducted on newly diagnosed patients of HIV who were attending HIV/AIDS clinic.

\section{Exclusion Criteria}

- Pregnant women.

- Patients under 16 years of age.

- Patients of malignancy not related to HIV disease.

- Patients not given consent.

\section{Statistical Methods}

Descriptive statistics were expressed as mean \pm standard deviation and results on categorical measurements as numbers (\%).Comparison between data was done by using chi-square test, student $\mathrm{T}$ test and ANOVA test Statistical analysis was done using SPSS 16.0 version, $\mathrm{P}<0.05$ statistically significant.

\section{RESULTS}

Demographic Data: Out of 100 patients included in this study, $58 \%$ (58) were males against $42 \%$ (42) females with the sex ratio of 1.38:1. Most of the males (50\%) and females (45\%) were in the age group of 31-40 years. Minimum age of the patient was 19 years and maximum age was 61 years. Most common age group was 21-40 years with mean age of $36.59 \pm$ 9.12 (Table -1)

\section{Clinical Presentation and CD4 Counts}

Clinical profile and haematological parameters of these patients were analysed. $60 \%$ of the patients were symptomatic at the time of presentation and presented with one or more than one clinical symptom such as fever, recurrent loose motions, anaemia, generalized weakness, arthralgia, tuberculosis, weight loss, seizures, oral ulcers skin lesions etc. and $40 \%$ patients were asymptomatic. Fever $(23.33 \%)$ was the major clinical presentation followed by diarrhoea (16.66\%) and extrapulmonary tuberculosis. (Table 2)

Patients were divided into three categories depending on CD4 counts; category 1 -less than 200 cells/ $\mu \mathrm{L}$, category 2 200 to 499 cells/ $\mu \mathrm{L}$ and category 3 -more than 500 cells/ $\mu \mathrm{L} 6$ Parinitha SS and Kulkarni MH, 2012). Most patients belonged to category $2(57 \%)$.

Anaemia was the most common haematological abnormality at the time of presentation in these patients. Among the total of 100 cases, 93 (93\%) cases had anaemia and $7(7 \%)$ cases had normal haemoglobin at the time of presentation. (Table 3)

Most common pattern of anaemia was normocytic normochromic in $42 \%$ cases followed by normocytic hypochromic in $25(25 \%)$ cases, microcytic hypochromic in $23(23 \%)$ cases and macrocytic in $10(10 \%)$ of cases (Table4).

Other haematological abnormalities detected were leucopenia in $2 \%$ of cases, neutropenia in $3 \%$ of cases, lymphocytopenia in $18 \%$ of cases and thrombocytopenia in 9 $\%$ of cases at the time of presentation. RBC count was less than lower limit of normal in $28 \%$ of females and $49 \%$ of males at the time of presentation (Table-5).
Correlation of various haematological parameters with different $\mathrm{CD} 4$ counts were done using chi square test, student $\mathrm{T}$ test and ANOVA test At the time of presentation, mean haemoglobin in patients with CD4 count $<200$ was $9.02 \pm$ 1.33 , in patients with CD4 count in between 200-499 was $10.48 \pm 1.73$ and in those having CD4 count $>500$ was $10.45 \pm$ 2.26. Patients with lower CD4 counts had more anaemic as compared to those having higher CD4 counts ( $p<0.0001)$. Red blood cell count and absolute lymphocyte count also showed statically significant correlation between different ranges of CD4 cell counts $(\mathrm{p}<0.056)$. Total leukocyte count, absolute neutrophil count and platelet count did not show statistically significant correlation (Table-6).

\section{DISCUSSION}

The present study was done in order to bring out the common haematological abnormalities encountered in HIV infection which is very important with the continuing rise in the prevalence of HIV infection in a developing country like India and to correlate these abnormalities with CD4 cell count, so that they can be used as a prognostic marker in resource limited settings.

In present study, the result of data analysis obtained shows a predominance of males amongst 100 patients that is males constituted $58 \%(n=58)$ with male: female ratio of 1.38:1. Similar sex distribution results were obtained in studies of ${ }^{7}$ with a male to female sex ratio of 1.12:1 and ${ }^{8}$ with a male to female sex ratio of 1.9:1.

The patient age in the present study was from more than 16 years and $71 \%$ of the patients were in the age group of 21 to 40 years with mean age of $36.59 \pm 9.12$, which as per the fact is the sexually active part of life as well as highly productive age group.This is comparable with the findings of ${ }^{7}$ where majority of the patients 21 to 40 years. This is also consistent with the findings of 8 , mean age of $39.8 \pm 10.7$.6 Parinitha SS and Kulkarni MH showed similar results with mean age of $34.55 \pm 9.63$. In the present study compared to male age distribution, females were younger, $35.71 \%$ of them were between 21 to 30 years of age group.

In our study, patients presented with various clinical symptoms like generalised weakness, fever loose motions, loss of appetite, skin lesions, oral lesions joint pains genital lesions etc. fever was the most common clinical presentation $23.33 \%$ cases followed by diarrhoea $16.66 \%$ and extrapulmonary tuberculosis $7 \%$.

Haematological changes have been accepted as powerful determining predictors of morbidity and mortality in HIVinfected patients. ${ }^{9}$ It has been demonstrated that severe anaemia is linked with faster rate of HIV disease progression. ${ }^{10}$ Haematological abnormalities commonly encountered in HIV- infected individuals are anaemia, granulocyte disorders, thrombocytopenia, lymphomas, coagulopathies and vascular malignancies like Kaposi sarcoma. Although in majority of cases, haematological abnormalities are detected in middle or advanced stages of HIV infection, some of these like anaemia and thrombocytopenia have been reported to occur in early stages of HIV infection. ${ }^{11}$

Anaemia is the most common cytopenia in HIV-infected individuals, occurring in $10-20 \%$ of patients at initial presentation and diagnosed in approximately $70-80 \%$ of 
patients over the course of disease. The incidence is strongly related with the progression of the disease and is common in the symptomatic group. ${ }^{12,13,14,4,15,1}$

In our study anaemia was present in $93 \%$ of cases. A similar observation was made by 16 in $34 / 40$ (85\%) cases. 17 reported anaemia in 175/197 (89\%) patients, and 18 in 61/74 $(82.4 \%)$ patients. However, 19 reported anaemia in $27 / 42$ $(64.2 \%)$ cases which is much lower as compared to the present study. Table-7 shows a comparison of number of anaemia cases in the present study with other studies. Of these, severe anaemia was observed in $6 \%$ of cases as compared to 7\% ( 1 Wanchu A et al.,2009), 18.5\% ( ${ }^{20}$ Meidani A et al., 2012), 33\% ( ${ }^{4}$ Kasthuri AS et al.,2006) in various studies. $46 \%$ patients were moderately anaemic, $41 \%$ patients had mild anaemia and $7 \%$ patients had no anaemia. Overall frequency of anaemia in our study was comparable with other studies.

The most common type of anaemia was normocytic normochromic type in $35 \%$ of cases. A similar observation was made by ${ }^{6}$ Parinitha et al., 2012 in $40.4 \%$ cases and by ${ }^{21}$ Khandekar et al., 2005 in $48.57 \%$ cases. Microcytic hypochromic anaemia was seen in $23 \%$ cases, normocytic hypochromic anaemia in $25 \%$ of cases and macrocytic in $10 \%$ of cases. 9\% cases had thrombocytopenia which in agreement with the study carried by22 Patwardhan et al., (2002) who had found thrombocytopenia in $13 \%$ of the cases. ${ }^{23}$ Sullivan et al., (1997) reported one year incidence of thrombocytopenia in 8.7\% persons with one or more AIDS defining illness. We also observed leucopenia in $2 \%$ patients and neutropenia in $3 \%$ of cases. Neutropenia tend to occur concomitantly with anaemia, 10 to $30 \%$ of those with ARC may be neutropenic, this may progress to about three-quarters of those with AIDS (24Zon et al., 1987). Lymphopenia was seen in $18 \%$ of the cases. Similar observations was made by 18 Tripathi et al., (2005) in $25.6 \%$ cases.

CD4 lymphocyte count is essential for assessment of immune status in HIV- infected persons as the pathogenesis of AIDS is largely attributed to a decrease in absolute CD4 cell counts. Patients in the present study were divided into three groups based on CD4 lymphocyte count.

The relation of haematological parameters with CD4 count was statically significant in relation to haemoglobin and RBC count $(\mathrm{p}<0.0001)$. 25 Vanisri et al., (2016)also found significant correlation of RBC parameters with CD4 cell count except for red blood cell count. More incidence of anaemia was seen in patients with CD4 counts $<200$ as compared to those having higher CD4 counts. No statically significant correlation was found between total leukocyte count, and absolute neutrophil count in relation to CD4 counts although counts were lower in patients with CD4 counts $<200$ and slightly higher in those having higher CD4 counts. ${ }^{8}$ Devi CS et al., (2016) also found lower counts in patients with decreasing CD4 cell counts and in her study also no significant correlation between total leukocyte count, absolute lymphocyte count and absolute neutrophil count was found. ${ }^{6}$ Parinitha et al., (2012) also found similar correlation of CD4 count with total leukocyte count as lower counts in patients with low CD4 cell count.

\section{CONCLUSIONS}

HIV affects virtually all organ systems, with well-known abnormalities related to hematopoietic system. Anaemia being the most common abnormality, has strong correlation with CD4 counts and therefore could be used to predict the development of a more advanced disease. The recent surge of HIV infection has led to an increase in the incidence of haematological abnormalities. Early detection, exact cause and appropriate treatment of these abnormalities will reduce morbidity and mortality in HIV/AIDS patients. At the same time, campaign for health education and preventive measures should be a continuous process so that the affected individuals will come forward to these designated centers and avail the facilities. Heath workers, social organisation and civil society should be educated so that they are aware of this permanent infection and take appropriate measures at all levels and this will help to overcome the inhibition of social stigma attached to it. Further studies on more number of patients will provide better understanding of overall behaviour and prognosis of disease.

\section{REFERENCES}

[1] Wanchu A, Dikshit B, Kaur KS, et al. Profile of heamatological abnormality of Indian HIV infected individual in PGI Chandigarh over a period of 2 years from 2007-09 India when sample size $n=200$. In this study also show anaemia is most common haematological finding in HIV positive cases. BMC Blood Disorders 2009;9:5.

[2] Dhurve SA, Dhurve AS. Comparison of peripheral smear findings with bone marrow findings in HIV patients. Sch J Appl Med Sci 2014;2(2C):711-7.

[3] WHO global program on AIDS. Current and future dimensions of HIV/AIDS pandemic a capsule summary. WHO, Geneva, April 1991.

[4] Kasthuri AS, Sharma S, Kar PK. A study of haematological manifestation of HIV infection at HIV tertiary care center over a period time March 1998 to August 1999. Majority was inpatient and a few outpatients Bangalore. Sample size $(n=100)$ HIV infected patient. Indian Journal Sex Transmission Disease 2006;27:9-16.

[5] Simoes EA, Babu PG, John TJ, et al. Evidence for HTLVIII infection in prostitutes in Tamil Nadu (India). Ind J Med Res 1987;85:335-8.

[6] Parinitha S, Kulkarni M. Haematological changes in HIV infection with correlation to CD4 cell count. Australas Med J 2012;5(3):157-62.

[7] Mitra JK, Horo SM. Analysis of haematological profile in HIV positive patients before and after antiretroviral therapy. Int J Health Sci Res 2015;5(11):18-24.

[8] Devi CS, Satish S, Gupta M. A study of haematological profile in human immune deficiency virus infection: correlation with CD4 counts. Ann Pathol Lab Med 2016;3:484-9.

[9] Doukas MA. Human immunodeficiency virus associated anaemia. Med Clin North Am 1992;76 (3):699-709.

[10] Mocroft A, Kirk O, Barton SE, et al. Anaemia is an independent predictive marker for clinical prognosis in HIV-infected patients from across Europe. EuroSIDA study group. AIDS 1999;13(8):943-50.

[11] Basu A, Ghosh K, Banerjee K. Bone marrow involvement in HIV infection: light, electron and 
immuno electron microscopic studies. Indian J Hematol \& Blood Transf 1999;17(4):76-86.

[12] Spira TJ, Jones BM, Nicholson JK, et al. Idiopathic CD4+ T-lymphocytopenia - an analysis of five patients with unexplained opportunistic infections. N Engl J Med 1993;328(6):386-92.

[13] Laurence J, Mitra D, Steiner M, et al. Apoptotic depletion of $\mathrm{CD} 4+\mathrm{T}$ cells in idiopathic CD4+ T lymphocytopenia. J Clin Invest 1996;97(3):672-80.

[14] Sloand E. Haematological complications of HIV infection. AIDS Rev 2005;7(4):187-96.

[15] Mehta PS. Haematological manifestations of HIV/ AIDS. HIV Curriculum. $4^{\text {th }}$ edn. 2007: p. 222-8.

[16] Kaloutsi V, Kohlmeyer U, Maschek H, et al. Comparison of bone marrow and haematological findings in patients with human immunodeficiency virus infection and those with myelodysplastic syndromes and infectious diseases. Am J Clin Pathol 1994;101(2):1239.

[17] Karcher DS, Frost AR. Bone marrow in human immunodeficiency virus (HIV)-related disease morphology and clinical correlation. Am J Clin Pathol 1991;95(1):63-71.

[18] Tripathi AK, Karla P, Misra R, et al. Study of bone marrow abnormalities in patients with HIV disease. J Assoc Physicians India 2005;53:105-10.
[19] Sitalakshmi S, Srikrishna A, Damodar P. Haematological changes in HIV infection. Ind J Pathol Microbiol 2003;46(2):180-3.

[20] Meidani M, Rezaei F, Maracy MR, et al. Prevalence, severity and related factors of anaemia in HIV/AIDS patients. J Res Med Sci 2012;17(2):138-42.

[21] Khandekar MM, Deshmukh SD, Holla VV, et al. Profile of bone marrow examination in HIV/AIDS patients to detect opportunistic infections, especially tuberculosis. Indian J Pathol Microbiol 2005;48(1):712.

[22] Patwardhan MS, Golwilkar AS, Abhyanakar JR, et al. Haematological profile of HIV positive patients. Indian J Pathol Microbiol 2002;45(2):147-50.

[23] Sullivan PS, Hanson DL, Chu SY, et al. Surveillence for thrombocytopenia in persons infected with HIV: results from the multistate adult and adolescent spectrum of disease project. J Acquir Immune Defic Syndr Hum Retrovirol 1997;14(4):374-9.

[24] Zon LI, Arkin C, Groopman JE. Haematological manifestations of the human immune deficiency virus (HIV). Br J Hematol 1987;66(2):251-6.

[25] Vanisri HR, Vadiraja N. Relationship between Red blood cell parameters and immune status in HIV infected females. Ind J Pathol Oncol 2016;3(2):255-9. 